\title{
Antibacterial activity and phytochemical screening of Kesambi (Sapindaceae) against Eschericia coli and Staphylococcus aureus
}

\author{
Boima Situmeang $^{1 *}$, Agus Malik Ibrahim $^{1}$, Nurhayati Bialangi ${ }^{2}$, Weny J.A Musa ${ }^{2}$, Saronom \\ Silaban ${ }^{3}$ \\ 'Department of Chemistry, Sekolah Tinggi Analis Kimia Cilegon, Cilegon, Indonesia \\ ${ }^{2}$ Department of Chemistry, Faculty of Mathematic and Natural Science, Gorontalo State University, Indonesia \\ ${ }^{3}$ Department of Chemistry, Faculty of Mathematic and Natural Science, Universitas Negeri Medan, Medan 2022l, Indonesia
}

\section{Abstract:}

Kesambi plant (Schleichera oleosa) is a medicinal plant belongs to family Sapindaceae, commonly found in tropical and subtropical regions of the world. In Indonesia, kesambi plants can be found in Java and Bali island. The purpose of this study is to extraction and antibacterial activity test of steam bark extract of kesambi against Escherichia coli and Staphylococcus aureus. Extraction was done by maceration method using $n$-hexane, ethyl acetate and methanol. Antibacerial test using Kirby bauer method by measure inhibition zone. Phytochemical screening shown that $n$-hexane extract contain triterpenes and steroid compounds. Ethyl acetate extract contain triterpenes, flavonoid, steroid, and fenolic compounds. Methanol extract contain flavonoid, fenolic and triterpenes compounds. Inhibition zone of $n$-hexane, ethyl acetate and methanol extracts against $E$. coliand $S$. aureus at concentration of $5000 \mu \mathrm{g} / \mathrm{mL}$ showed 4.4; 7.9; $4.6 \mathrm{~mm}$ and 4.7; 8.9; 4.5 respectively, while amoxicillin and ciprofloxacin as positive control at concentration of $100 \mu \mathrm{g} / \mathrm{mL}$ showed 6.9 and $7.1 \mathrm{~mm}$ respectively. Kesambi extract have potential as antibacterial against $E$. coli and $S$. aureus.

\section{Keywords:}

Kesambi; antibacterial; Eschericia coli; Staphylococus aureus

\section{Introduction}

Infectious disease and parasites are one of the major diseases in the world. According to World Health Organization (WHO) data in 2011, infectious and paracites diseases are the third leading cause of death in the world. In Indonesia, infection deseases is one of the major caused of death for children and still a big health problem in all levels of society (Singh \& Pandeya, 2011). Infectious disease of the skin tissue that commonly affects the public caused by various bacteria (Mustaffa et al. 2011). Bacteria cause the most common skin disease and infection is Staphylococcus aureus and Escherichia coli. One of the palnt that have potential to treat various deseases is Kesambi. Schleichera oleosa (Kesambi) is well known as medicinal plant (Dhego et al. 2017). Kesambi is one of plants that have the potential to treat various deasease. Kesambi plant

\footnotetext{
* Corresponding author.

boima@stakc.ac.id

doi: https://doi.org/10.2 4114/jpkim.vlli 1.13078
}

or kusum widely spread in Asia such as India, Nepal, Malaysia and Indonesia (Anuragi \& Mishra, 2017). In Indonesia, this plant can be found in Java and Bali island especially in Cilegon region (Ghosh et al. 2011; Situmeang et al. 2016). The presence of various types of phytochemicals such as tannins, alkaloids, glycosides, volatile oils etc. showed that the plant possesses considerable medicinal importance (Bachli, 2007;). The storage organs of the plant contains these active principles. Kesambi is an important multipurpose ethnomedicinal plant with basic and applied importance to civil as well as tribal society.

Natural products have been a source of medicinal agents and traditional medicine system that have been used for thousand of years in countries. World Health Organization also has been estimated that approximately $80 \%$ of the world's inhabitans rely mainly on traditional medicines for their primary health care (Singh \& Pandeya, 2011). As the plant is being used extensively in Indonesia as an herbal medicine, it is necessary to have knowledge of antibacterial 
activity against $E$. coli and $S$. aureus of the plant of our native species.

\section{Materials and Methods}

Material and instrumentation

The research specimen is kesambi steam bark collected from Cimerak vilage, Cilegon district, Banten province, Indonesia in march 2019. The chemicals used in this research were ethyl acetate, $n$-hexane, methanol, distilled water, alcohol $70 \%$, ciprofloxacin $100 \mathrm{ppm}$, amoxycilin $100 \mathrm{ppm}$, bacto agar, and Nutrien broth media. Instrument were used laminar air flow, memmert incubator, hirayama HVE-50 autoclave, Erlenmeyer, paper disc, micro plates, micro tubes, micro pipets and evaporator.

\section{Extraction}

Dried kesambi steam bark (2 $\mathrm{kg})$ were soaked in $5 \mathrm{~L} n$-hexane, ethyl acetate and methanol solvent for 2 days respectively. The shole mixture was then filtered through filter paper and the filtrate was then evaporated under reduce pressure at $50^{\circ} \mathrm{C}$ using a Buchi rotary evaporator. All the extracts were filtered through a cotton plug followed by Whatman filter paper and then concentrated by using a rotary vacum evaporator to provide of $\mathrm{n}$-hexana, ethyl acetate, and of methanol crude extract. All extract were test phytochemical screening (Marlinda et al. 2012; Situmeang et al. 2016).

\section{Antibacterial activity test}

Selected bacteria (E. coli and S. aureus) was cultured for $24 \mathrm{~h}$ at $37^{\circ} \mathrm{C}$ under aerobic condition on nutrient broth media. Afterward, the bacteria were suspended in a $0.8 \%$ Nutrion broth solution $(w / v)$. The turbidity of suspension of bacteria was corrected to the $0.5 \mathrm{Mc}$ Farland standard $\left(1.2 \times 10^{8}\right.$ bacterial cells $/ \mathrm{mL}$ ). Agar plate was inoculated with $200 \mu \mathrm{L}$ bacterial suspension. $15 \mu \mathrm{L}$ of the sample with concentrations of $5000 \mu \mathrm{g} /$ were dripped on paper disc on agar media and incubated for $24 \mathrm{~h}$ at $37{ }^{\circ} \mathrm{C}$ under aerobic condition. The presence of clear zones around the paper disc was indicated that the samples has antibacterial activity. The assays were also carried out to the negative control (methanol 96\%) and standard antibiotic amoxicillin and ciprofloxacin (positive control) with concentration $100 \mu \mathrm{g} / \mathrm{L}$. The inhibition zone of the sample was determined by measuring the diameter of the clear zone around the paper disc. The assays were conducted in two repetitions (Roslizawaty et al. 2013; Dhego et al. 2017). The research flow chart shown in Fig 1.

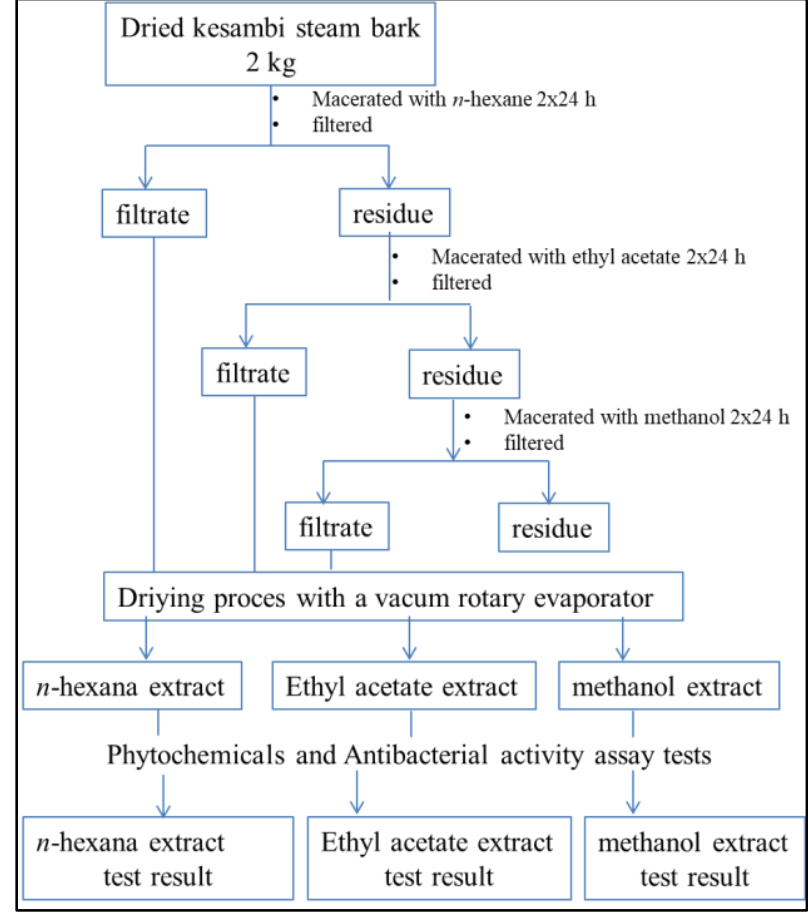

Fig 1. Research flow chart

\section{Results}

The steam bark of kesambi was dried and successively extracted with $n$-hexane, ethyl acetate and methanol solvent. All extract were phytochemical screening test using several reagent. Phytochemical screening shown thant $n$ hexane extract contain triterpenes and steroid compounds. Ethyl acetate extract contain triterpenes, flavonoid, steroid, and fenolic compounds. Methanol extract contain flavonoid, fenolic and triterpenes compounds. The result of $n$-hexane extract were $5 \mathrm{~g}$, ethyl acetate $17 \mathrm{~g}$, and methanol $297 \mathrm{~g}$. the result of antibacterial acivity test shown in Table 1.

Antibacterial activity test shown ethyl acetate extract has the high inhibition zone against $E$. coli and $S$. aureus (Fig 2). Amoxicillin and ciprofloxacin as positive control with concentration of $100 \mu \mathrm{g} / \mathrm{mL}$ showed high inhibition zone. Amoxicillin at concentration 100 ppm gives $6.9 \mathrm{ppm}$ and ciprofloxacin gives $7.1 \mathrm{~mm}$ (Fig 3).

\section{Discussion}

The resulted of extraction shown that methanol extract have the much quantity with red colour compared with $n$-hexana and ethyl acetate extract. This result indicated that kesambi extract contain more polar chemical compounds that nonpolar. The result of phytochemical screening shown that kesambi steam bark extract positive contain 
triterpenoid in all solvent phases. Positive flavonoids and fenolic compounds in ethyl acetate and methanol extract, while steroids positive in $n$ hexana and ethyl acetate. This is concictent according to Schleichera oleosa steam bark reported by Srinivas \& Baboo (2013) and Dhego et al. (2017).

Antibacterial activity test shown ethyl acetate extract has the high inhibition zone against $E$. coli and $S$. aureus. This is correlated that ethyl acetate extract contains much chemical compounds than n-hexana and methanol extract (Ajileye et al. 2015). E. coli and $S$. aureus are aerobic bacteria. This is the first reported antibacterial activity test from kesambi steam bark extract collected from Cimerak village, Indonesia.

Amoxicillin and ciprofloxacin as positive control with concentration of $100 \mu \mathrm{g} / \mathrm{mL}$ showed high inhibition zone. Amoxicillin choosed as positive control because amoxicillin is one of several antibiotic which used by people to treat diarrhea desease (Edziri et al. 2012; Favela-Hernández et al. 2012; Febrina et al. 2017; Simorangkir et al. 2017). Methanol as negative control not shown inhibition zone. Its means that bacteria $E$. coli and $S$. aureus not gives effect or inhibition zone.

Table 1

Antibacterial activity test of steam bark kesambi extract

\begin{tabular}{lccc}
\hline \multirow{2}{*}{ Sample } & Concentration & \multicolumn{2}{c}{ lnhibition zone $(\mathrm{mm})$} \\
\cline { 2 - 4 } & $\mu \mathrm{g} / \mathrm{L}$ & E. coli & S. aureus \\
\hline n-hexane & 5000 & 4.4 & 4.7 \\
Ethyl acetate & 5000 & 7.9 & 8.9 \\
Methanol & 5000 & 4.3 & 4.5 \\
Amoxicillin & 100 & 6.9 & $\mathrm{nt}$ \\
Ciprofloxacin & 100 & $\mathrm{nt}$ & 7.1 \\
Methanol & $96 \%$ & 0 & 0 \\
\hline
\end{tabular}

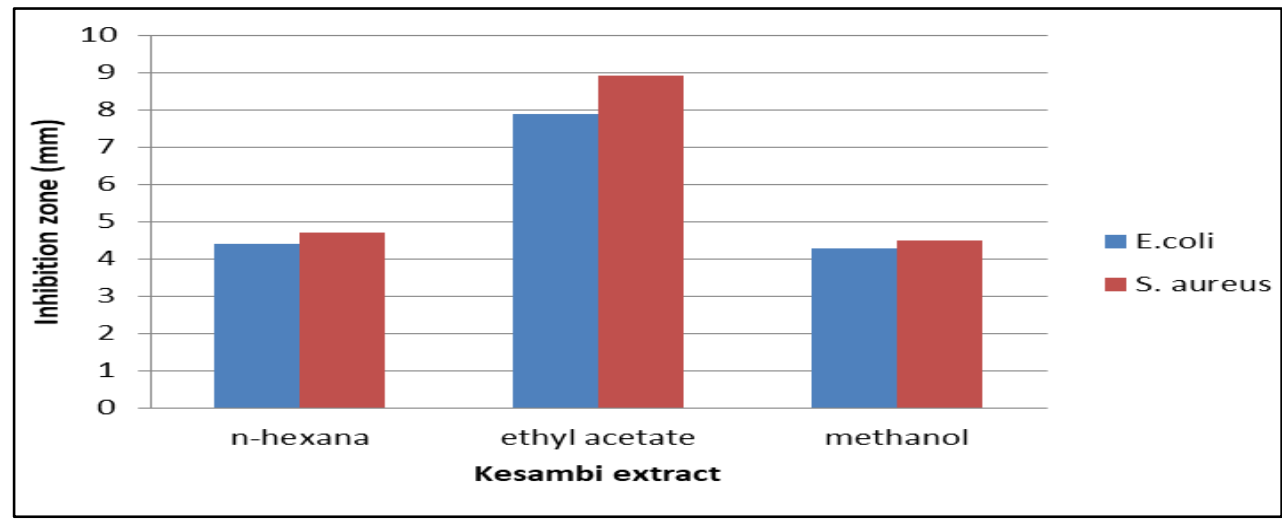

Fig 2. Diagram of antibacterial activity

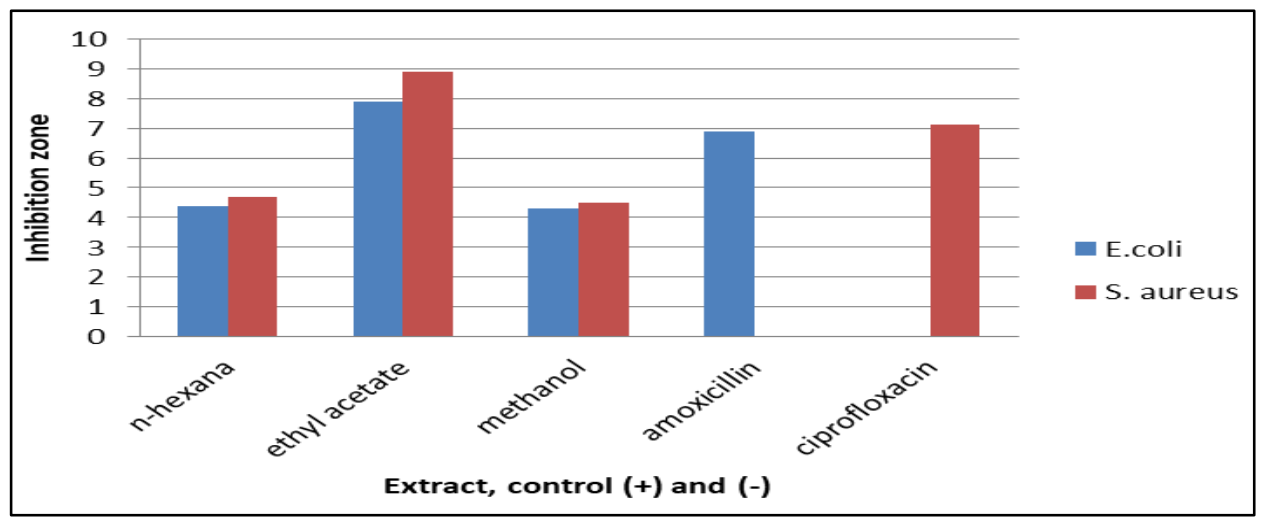

Fig 3. Extract, positive control and negative control 


\section{Conclusion}

Phytochemical screening shown thant $n$-hexane extract contain triterpenes and steroid compounds. Ethyl acetate extract contain triterpenes, flavonoid, steroid, and fenolic compounds. Methanol extract contain flavonoid, fenolic and triterpenes compounds. Antibacterial activity test shown that ethyl acetate and methanol extract have higher inhibition zone value. Inhibition zone of $n$-hexane, ethyl acetate and methanol extracts against $E$. coli and $S$. aureus at concentration of $5000 \mu \mathrm{g} / \mathrm{mL}$ showed 4.4; 7.9; $4.6 \mathrm{~mm}$ and $4.7 ; 8.9 ; 4.5$ respectively, while amoxicillin and ciprofloxacin as positive control at concentration of $100 \mu \mathrm{g} / \mathrm{mL}$ showed 6.9 and 7.1 $\mathrm{mm}$ respectively.

\section{Acknowledgments}

The author thank the ministry of research and higher education of the Indonesia Republic for funding this research (RISTEKDIKTI) and central laboratory Padjadjaran University.

\section{References}

Anuragi, J. L., \& Mishra, R. P. (2017). Ethnomedicinal study of Schleichera oleosa among the tribals of Satna (MP). International Journal of Applied Research, 3(3), 672-674.

Ajileye, O. O., Obuotor, E. M., Akinkunmi, E. O., \& Aderogba, M. A. (2015). lsolation and characterization of antioxidant and antimicrobial compounds from Anacardium occidentale L. (Anacardiaceae) leaf extract. Journal of King Saud University - Science, 27(3), 244-252, doi: 10.1016/j.jksus.2014.12.004.

Bachli, Y. 2007. Tanaman kesambi dan beternak kutu untuk kesejahteraan. Buletin BPTP, 1(3).

Dhego, A. P., Susanti, L., \& Wibawa, D. A. A. (2017). Uji aktivitas antibakteri salep ekstrak kulit batang Kesambi (Schleichera oleosa Merr) terhadap Staphylococcus aureus ATCC 25923 yang diinfeksikan pada Kelinci. Biomedika, $10(2), 11-17$.

Edziri, H., Mastouri, M., Mahjoub, M. A., Mighri, Z., Mahjoub, A., \& Verschaeve, L. (2012). Antibacterial, antifungal and cytotoxic activities of two flavonoids from Retama raetam flowers. Molecules, 17(6), 7284-7293, doi: $10.3390 /$ molecules 17067284 .

Favela-Hernández, J. M. J., García, A., GarzaGonzález, E., Rivas-Galindo, V. M., \& CamachoCorona, M. R. (2012). Antibacterial and antimycobacterial lignans and flavonoids from
Larrea tridentata. Phytotherapy Research, 26(12), 1957-1960, doi: 10.1002/ptr.4660.

Febrina, L., Riris, I. D., \& Silaban, S. (2017). Uji aktivitas antibakteri terhadap Escherichia coli dan antioksidan dari ekstrak air tumbuhan binara (Artemisia vulgaris L.). Jurnal Pendidikan Kimia, 9(2), 311-317, doi: 10.24114/jpkim.v9i2.7621.

Ghosh, P., Mandal, A., Chakraborty, M., Chakraborty, P., Rasul, M., \& Saha, A. (2011). Triterpenoids from Schleichera oleosa of Darjeeling foothills and their antimicrobial activity. Indian Journal of Pharmaceutical Sciences, 73(2), 231, doi: 10.4103/0250474x.91568.

Marlinda, M., Sangi, M. S., \& Wuntu, A. D. (2012). Analisis senyawa metabolit sekunder dan uji toksisitas ekstrak etanol biji buah alpukat (Persea americana Mill.). Jurnal MIPA Unsrat Online, 1(1), 24-28.

Mustaffa, F., Indurkar, J., Ismail, S., Shah, M., \& Mansor, S. M. (2011). An antimicrobial compound isolated from Cinnamomum iners Leaves with activity against methicillin-resistant Staphylococcus aureus. Molecules, 16(4), 30373047, doi: 10.3390/molecules16043037.

Roslizawaty, Ramadani N. Y, Fakhrurrazi, Herrialfian. (2013) Aktivitas antibakterial ekstrak etanol dan rebusan sarang semut (Myrmecodia sp.) terhadap bakteri Escherichia coli. Jurnal Medika Veterinaria, 7(2), 91-94, http://dx.doi.org/10.21157/j.med.vet..v7i2.2938.

Simorangkir, M., Silaban, S., Surbakti, R., Barus, T., \& Simanjuntak, P. (2017). Aktivitas antikanker ekstrak etanol buah Ranti Hitam (Solanum blumei Nees ex Blume) terhadap sel leukimia L1210. Chimica et Natura Acta, 5(1), 31-35, doi: 10.24198/cna.v5.n1.12819.

Singh, G. S., \& Pandeya, S. N. (2011). Natural products in discovery of potential and safer antibacterial agents. Opportunity, Challenge and Scope of Natural Products in Medicinal Chemistry, 63-101.

Situmeang, B., Nuraeni, W., lbrahim, A. M., \& Silaban, S. (2016). Analysis of secondary metabolite compounds from leaves extract kesambi (Schleichera oleosa) and antioxidant activity test. Jurnal Pendidikan Kimia, 8(3), 164168.

Srinivas, K., \& Baboo, C. R. V. (2013). Antioxidant activity of ethanolic extract of stem bark of Schleichera oleosa (Lour. Oken). Inter. J. of Pharmacotherapy, 3(1), 12-14. 